\title{
Abundance and morphology of virus-like particles associated with the coral Acropora hyacinthus differ between healthy and white syndrome-infected states
}

\author{
F. Joseph Pollock ${ }^{1,2,3, *, * *}$, Elisha M. Wood-Charlson ${ }^{1, * *}$, Madeleine J. H. van Oppen ${ }^{1,3}$, \\ David G. Bourne ${ }^{1}$, Bette L. Willis ${ }^{2,3}$, Karen D. Weynberg ${ }^{1, * * *}$ \\ ${ }^{1}$ Australian Institute of Marine Science, Townsville, Queensland, Australia \\ ${ }^{2}$ School of Marine and Tropical Biology, and ${ }^{3}$ ARC Centre of Excellence for Coral Reef Studies; James Cook University, \\ Townsville, Queensland, Australia
}

\begin{abstract}
Disease outbreaks are implicated in coral reef degradation worldwide, but little is known about the role of viruses in coral health. In this study, transmission electron microscopy (TEM) was employed in parallel with flow cytometry to compare viral communities associated with visually healthy and white syndrome (WS)-infected tissues of the coral Acropora hyacinthus at Lizard Island on Australia's northern Great Barrier Reef. Viral community shifts were observed on WS-infected corals that were characterized by higher abundance, smaller size and distinct morphology of virus-like particles (VLPs) on disease lesions relative to healthy tissues. Coral tissues displaying WS contained $65 \%$ more VLPs, with $87 \%$ of these falling in the sub-100 nm size range, compared to only $7 \%$ from healthy tissues. While the observed viral community shifts are not necessarily indicative of disease causation, they may provide diagnostic criteria to discriminate between distinct, but macroscopically similar, WS and WS-like coral diseases. Furthermore, these results highlight the need to incorporate virology in investigations of coral health and disease.
\end{abstract}

KEY WORDS: Virus · Coral · Disease $\cdot$ White syndromes $\cdot$ Great Barrier Reef

\section{INTRODUCTION}

Coral diseases have fundamentally altered Caribbean coral reef ecosystems and pose a growing threat to Indo-Pacific reefs (Aronson \& Precht 2001, Willis et al. 2004, Bruno \& Selig 2007). In the past decade, a virulent group of coral diseases known as white syndromes (WS) have impacted reefs throughout the Indian, Pacific and Atlantic Oceans (Willis et al. 2004, Aeby 2005, Sussman et al. 2008, Long \& Holmes 2009, Hobbs \& Frisch 2010). In the Caribbean, WS-like tissue loss diseases (e.g. white plague and white band diseases) have contributed to dramatic reductions in cover of the once-dominant coral genus Acropora and subsequent phase-shifts on many reefs (Aronson \& Precht 2001, Weil et al. 2006, Vollmer \& Kline 2008). While identification of causative agents is critical for effective disease management (Pollock et al. 2011), no single etiological agent has yet been identified for WS. Proposed causative agents include bacteria, ciliates and helminths (Sussman et al. 2008, Work et al. 2011, 2012, Sweet \& Bythell 2012).

Viruses infect a wide range of bacteria, algae, fungi, plants, and invertebrate and vertebrate animals (Munn 2006), yet their role in coral disease causation in general, and WS in particular, remains unresolved. While the field of coral virology is still in its infancy, there is mounting evidence that corals 
harbor diverse viral assemblages targeting the myriad constituents of the coral holobiont (Wilson et al. 2005, Davy \& Patten 2007, Patten et al. 2008, Thurber \& Correa 2011). Coral-associated viral communities are highly dynamic, with virus-like particle (VLP) assemblage shifts observed in response to thermal stress and coral disease (Wilson et al. 2005, Davy et al. 2006, Patten et al. 2008, Soffer et al. 2014). However, previous investigations examining viruses associated with WS and WS-like diseases have yielded largely contradictory results (Patten et al. 2008, Soffer et al. 2014).

In order to determine the role of viruses in WS coral disease, we must first understand if and how viral communities differ between healthy and diseased coral tissues and determine how consistent these differences are among macroscopically similar disease signs over temporal and spatial scales. The current study examines viral communities associated with both visually healthy and WS-infected tissues of the coral Acropora hyacinthus, using transmission electron microscopy (TEM) and flow cytometry.

\section{MATERIALS AND METHODS}

Coral samples for this study were collected from Lizard Island $\left(14^{\circ} 40^{\prime} \mathrm{S}, 145^{\circ} 27^{\prime} \mathrm{E}\right)$, in the northern sector of the Great Barrier Reef (GBR), in January 2013. Samples were taken from 3 visually healthy and 3 WS-infected colonies (i.e. displaying diffuse, acute-to-sub-acute areas of tissue loss revealing white, intact skeleton) of $A$. hyacinthus (1 to $5 \mathrm{~m}$ depth) at Mermaid Cove, Lizard Island. One fragment, $\sim 50 \mathrm{~cm}^{2}$ in area, was collected from each healthy colony and 2 fragments (each $\sim 50 \mathrm{~cm}^{2}$ ) were collected from each WS-infected colony (i.e. one from the disease lesion interface and one from apparently healthy tissue approximately $10 \mathrm{~cm}$ away from the lesion). Coral fragments were placed in individual sterile bags underwater and subsequently stored on ice. Within 1 h, $25 \mathrm{ml}$ of sterile phosphate-buffered saline solution was added to each bag and the fragments were shaken vigorously by hand for 3 minutes to dislodge coral mucus and sloughing tissue. Eight replicate $1 \mathrm{ml}$ aliquots were collected from each bag, with 4 aliquots fixed in EM grade $0.5 \%$ glutaraldehyde and stored at $4^{\circ} \mathrm{C}$ for TEM and 4 aliquots fixed in $0.5 \%$ glutaraldehyde at $4^{\circ} \mathrm{C}$ for $30 \mathrm{~min}$, snap frozen in liquid nitrogen and stored at $-80^{\circ} \mathrm{C}$ for flow cytometry analyses.

Samples for TEM observation were negatively stained by suspending $10 \mu$ l of fixed sample on a
Formvar carbon-coated $200 \mu \mathrm{m}$ mesh copper grid for $1 \mathrm{~h}$. Excess liquid was wicked off with filter paper and each preparation was stained with uranyl acetate $(2 \%$ [wt/vol] in water) for 60 s. Prepared grids were examined with a JEOL 2100 TEM $(120 \mathrm{kV})$ and digitally acquired images were analyzed using ImageJ software.

Samples for flow cytometry were thawed, diluted with TE buffer, stained with $1 \times$ SYBR Green I (Invitrogen) at $80^{\circ} \mathrm{C}$ for 10 minutes in the dark and analyzed in a Becton Dickinson (BD) FACSVerse flow cytometer equipped with a $488 \mathrm{~nm}$ argon-ion laser and using the BD FACSuite software (see Brussaard 2004 for detailed methods). The FACSVerse cytometer overcomes the potential influence of laser drift through extensive calibration to BD's quality controlled, multi-colored bead standard that ensures consistent laser intensity and alignment between sample runs.

\section{RESULTS}

TEM analysis revealed a distinct population of virus-like particles (VLPs) associated with tissue and mucus at the WS diseased lesion front, relative to healthy samples. VLPs observed in diseased samples had electron-dense cores, capsids with icosahedral symmetry and diameters of $\sim 60-70 \mathrm{~nm}$ and occasionally $100 \mathrm{~nm}$ (Fig. 1A-F, n = 30 VLPs observed per health state from 3 biological replicates). VLPs from healthy samples were appreciably larger (diameters of $\sim 150 \mathrm{~nm}$ ) with discernible short tail structures (Fig. 1G-I). Quantitative analysis of the TEM results shows that $\sim 87 \%$ of the VLPs in diseased samples had diameters $<100 \mathrm{~nm}$ compared to only $7 \%$ of VLPs in healthy tissue samples.

Flow cytometry results corroborated the TEM analysis, showing increased numbers of relatively small VLPs from WS lesion fronts compared to healthy tissues. In the unique VLP gate, WS tissues $(3.6 \pm 0.6 \%$ of events, normalized to total number of events to account for any potential differences in tissue biomass between samples) had $65 \%$ more events than regions of healthy tissues collected from diseased colonies (2.2 \pm 0.3 ) (Fig. 2) and $37 \%$ more events than healthy tissues on apparently healthy corals $(2.6 \pm 0.5)$ (data not shown). Furthermore, a unique population of small VLPs dominated the WS viral communities (Fig. 2, Emiliania huxleyi virus, EhV, capsid diameter $\approx 170 \mathrm{~nm}$, genome size $\approx$ $400 \mathrm{kbp}$, is shown for reference in Fig. 2A). 

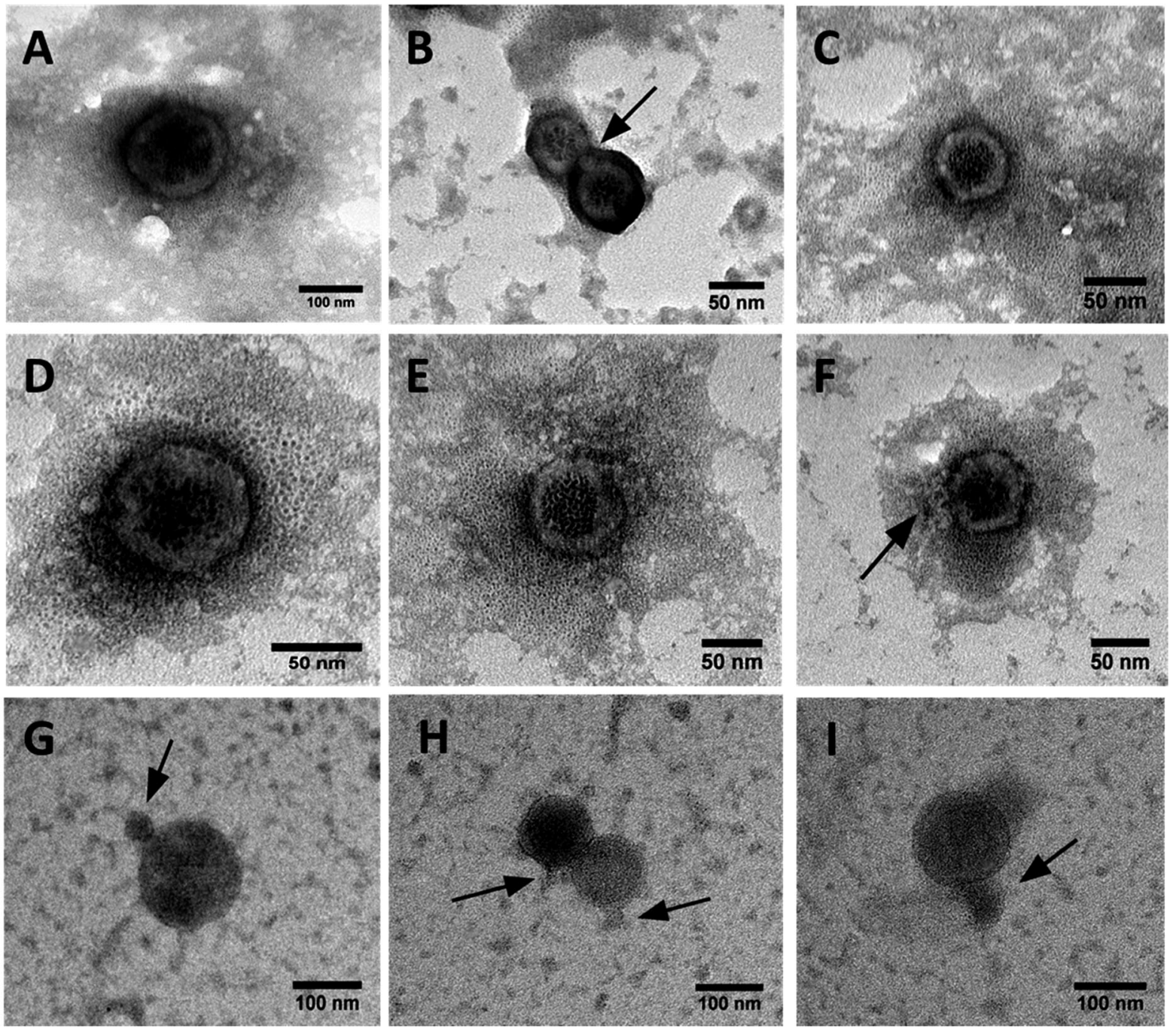

Fig. 1. Transmission electron microscopy images of virus-like particles seen in negatively stained tissue samples of the coral Acropora hyacinthus comparing: (A-F) diseased tissue collected from white syndrome-infected corals, $(\mathrm{G}, \mathrm{H}) \mathrm{healthy}$ tissue, and (I) tissue sampled $10 \mathrm{~cm}$ from a disease zone. Arrows indicate putative tail structures

\section{DISCUSSION}

Both TEM and flow cytometry analyses demonstrated smaller (sub-100 nm) and more abundant VLPs in WS-affected tissues of $A$. hyacinthus, compared to apparently healthy samples. Previous investigations examining viruses associated with WS and WS-like diseases have been contradictory. Patten et al. (2008) noted no difference in VLP abundance or size between healthy and WS-affected tissues of A. muricata from the Great Barrier Reef using a TEM approach. However, Soffer et al. (2014), utilizing TEM and amplicon pyrosequencing, reported elevated numbers of small $(\sim 20 \mathrm{~nm})$ viral particles with sequence similarities to small, circular, single- stranded DNA viruses (SCSDVs) in white plague diseased tissues of Montastrea annularis in the Caribbean. Our investigations into viruses associated with WS-affected corals also show an increase in VLPs under disease conditions and identified a distinct viral population that differed between healthy and diseased tissues of WS-affected corals. However, these shifts do not necessarily indicate a direct role in disease causation. Tissue loss associated with WS coincides with a suite of coral-associated assemblage shifts at both the microscopic and macroscopic levels (Sunagawa et al. 2009, Sweet \& Bythell 2012, Pollock et al. 2013). To fully understand this globally important group of diseases, it will be critical to unravel which of these changes arise as a cause of the 

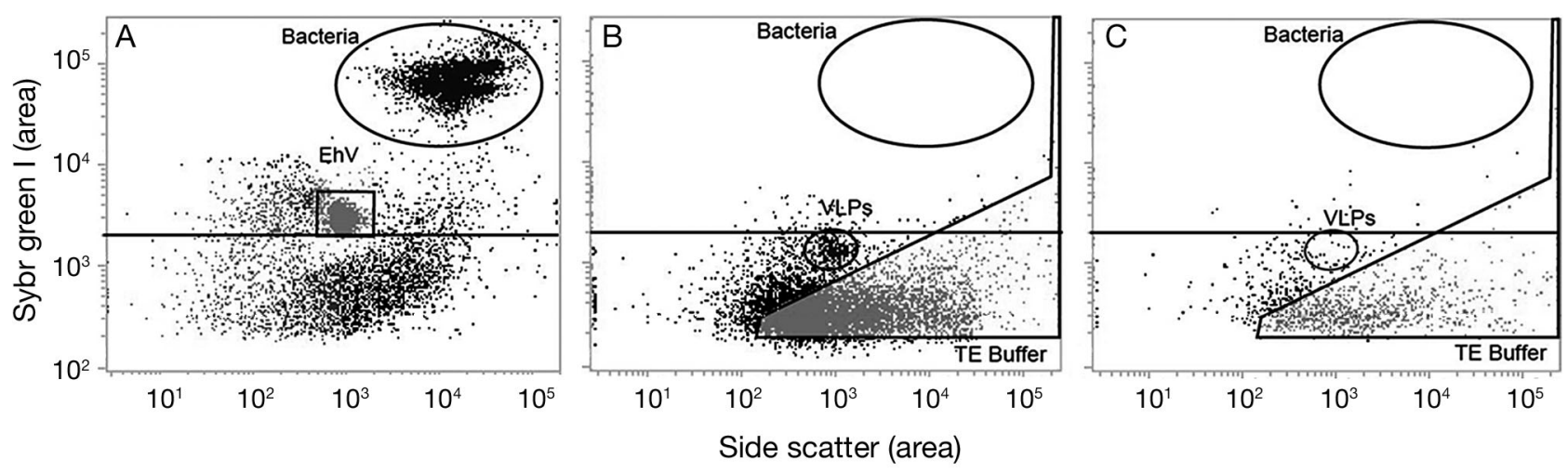

Fig. 2. Flow cytometry scatter plots of virus-like particles (VLPs) from corals affected by white syndrome (WS). (A) As a reference, a scatter plot of cultured Emiliania huxleyi virus (EhV, 170 nm diameter) (acquired with same laser settings for side scatter area and fluorescence staining of nucleic acids by Sybr Green I). Example scatter plots for samples from a (B) WS lesion front and (C) healthy tissue collected $10 \mathrm{~cm}$ from the WS lesion front. All coral samples were $0.2 \mu \mathrm{m}$ filtered prior to staining, so no bacterial population was detected. Solid lines indicate locations of bacteria, viruses and TE buffer

observed disease and which arise as a consequence (Lesser et al. 2007, Ainsworth et al. 2008).

As colonial animals with simple body plans, corals display a limited number of macroscopic signs indicative of stress and disease (Bourne et al. 2009, Pollock et al. 2011), and coral diseases are often manifested as a WS-like sloughing of the coral tissue. This has resulted in misidentification of diseases (Richardson 1998), multiple name changes for the same disease and misidentification of predation scars as disease (Bruckner \& Bruckner 2002). In order to better define disease etiologies and differentiate among diseases with similar macroscopic signs, detailed examination and description of bacterial and viral community dynamics are critical. While microbial community shifts may represent a secondary response to altered coral physiology and/or holobiont structure, they can provide important clues to disease etiology and may serve as diagnostic criteria to discriminate between distinct, but macroscopically similar diseases.

Future studies are needed to isolate and characterize WS-associated VLPs and identify their host(s) within the coral holobiont. To achieve this, carefully controlled infection challenges with putative viral (and/or other) pathogens are required (Work et al. 2008, Bourne et al. 2009). Even if these WS-associated viruses do not directly cause WS, more detailed knowledge of their identity, hosts and function will provide important clues to the etiology of this poorly understood group of diseases. Furthermore, by incorporating virology into future investigations, researchers could gain deeper insights into the numerous coral diseases and disease-like syndromes of currently unknown or disputed etiology.
Acknowledgements. This research was supported by an Australian Research Council Super Science Fellowship award to K.D.W. and by a Lizard Island Research Foundation Fellowship awarded to F.J.P. for study at Lizard Island Research Station, a facility of the Australian Museum. The authors gratefully acknowledge Peta Clode at the Centre of Microscopy, Characterisation and Microanalysis, University of Western Australia for assistance with electron microscopy as well as F. H. Pollock for assistance in the field.

\section{LITERATURE CITED}

Aeby GS (2005) Outbreak of coral disease in the northwestern Hawaiian Islands. Coral Reefs 24:481-481

Ainsworth TD, Fine M, Roff G, Hoegh-Guldberg O (2008) Bacteria are not the primary cause of bleaching in the Mediterranean coral Oculina patagonica. ISME J 2:67-73

Aronson RB, Precht WF (2001) White-band disease and the changing face of Caribbean coral reefs. Hydrobiologia 460:25-38

Bourne DG, Garren M, Work TM, Rosenberg E, Smith GW, Harvell CD (2009) Microbial disease and the coral holobiont. Trends Microbiol 17:554-562

Bruckner AW, Bruckner RJ (2002) Coral predation by Sparisima viride and lack of relationship with coral disease. In: Proc 9th Int Coral Reef Symp, p 1245-1249

Bruno JF, Selig ER (2007) Regional decline of coral cover in the Indo-Pacific: timing, extent, and subregional comparisons. PLoS ONE 2:e711

Brussaard CP (2004) Optimization of procedures for counting viruses by flow cytometry. Appl Environ Microbiol 70:1506-1513

Davy JE, Patten NL (2007) Morphological diversity of viruslike particles within the surface microlayer of scleractinian corals. Aquat Microb Ecol 47:37-44

Davy SK, Burchett SG, Dale AL, Davies P and others (2006) Viruses: agents of coral disease? Dis Aquat Org 69: 101-110

Hobbs JP, Frisch A (2010) Coral disease in the Indian Ocean: taxonomic susceptibility, spatial distribution and the role of host density on the prevalence of white syndrome. Dis Aquat Org 89:1-8 
Lesser MP, Bythell JC, Gates RD, Johnstone RW, HoeghGuldberg O (2007) Are infectious diseases really killing corals? Alternative interpretations of the experimental and ecological data. J Exp Mar Biol Ecol 346: 36-44

Long SC, Holmes TH (2009) Comparative marine biodiversity of the Rowley Shoals 2007: benthic assemblages. Marine Science Program, Department of Environment and Conservation, Perth, WA

> Munn CB (2006) Viruses as pathogens of marine organisms - from bacteria to whales. J Mar Biol Assoc UK 86: 453-467

Patten NL, Harrison PL, Mitchell JG (2008) Prevalence of virus-like particles within a staghorn scleractinian coral (Acropora muricata) from the Great Barrier Reef. Coral Reefs 27:569-580

Pollock FJ, Morris PJ, Willis BL, Bourne DG (2011) The urgent need for robust coral disease diagnostics. PLoS Pathogens 7:e1002183

> Pollock FJ, Katz SM, Bourne DG, Willis BL (2013) Cymo melanodactylus crabs slow progression of white syndrome lesions on corals. Coral Reefs 32:43-48

Richardson LL (1998) Coral diseases: what is really known? Trends Ecol Evol 13:438-443

Soffer N, Brandt ME, Correa AM, Smith TB, Thurber RV (2014) Potential role of viruses in white plague coral disease. ISME J 8:271-283

Sunagawa S, DeSantis TZ, Piceno YM, Brodie EL and others (2009) Bacterial diversity and White Plague Diseaseassociated community changes in the Caribbean coral Montastraea faveolata. ISME J 3:512-521

Editorial responsibility: Christine Paetzold,

Oldendorf/Luhe, Germany
Sussman M, Willis BL, Victor S, Bourne DG (2008) Coral pathogens identified for White Syndrome (WS) epizootics in the Indo-Pacific. PLoS ONE 3:e2393

> Sweet M, Bythell J (2012) Ciliate and bacterial communities associated with White Syndrome and Brown Band Disease in reef-building corals: Ciliate and bacterial pathogens in coral disease. Environ Microbiol 14: 2184-2199

> Thurber RLV, Correa A (2011) Viruses of reef-building scleractinian corals. J Exp Mar Biol Ecol 408:102-113

Vollmer SV, Kline DI (2008) Natural disease resistance in threatened staghorn corals. PLoS ONE 3:e3718

Weil E, Smith G, Gil-Agudelo DL (2006) Status and progress in coral reef disease research. Dis Aquat Org 69:1-7

Willis BE, Page CA, Dinsdale EA (2004) Coral disease on the Great Barrier Reef. In: Coral health and disease. Springer, Berlin, p 69-104

Wilson WH, Dale AL, Davy JE, Davy SK (2005) An enemy within? Observations of virus-like particles in reef corals. Coral Reefs 24:145-148

Work TM, Richardson LL, Reynolds TL, Willis BL (2008) Biomedical and veterinary science can increase our understanding of coral disease. J Exp Mar Biol Ecol 362:63-70

Work TM, Forsman ZH, Szabó Z, Lewis TD, Aeby GS, Toonen RJ (2011) Inter-specific coral chimerism: genetically distinct multicellular structures associated with tissue loss in Montipora capitata. PLoS ONE 6:e22869

Work TM, Russell R, Aeby GS (2012) Tissue loss (white syndrome) in the coral Montipora capitata is a dynamic disease with multiple host responses and potential causes. Proc R Soc B Biol Sci 279:4334-4341

Submitted: March 12, 2014; Accepted: June 24, 2014 Proofs received from author(s): August 27, 2014 